
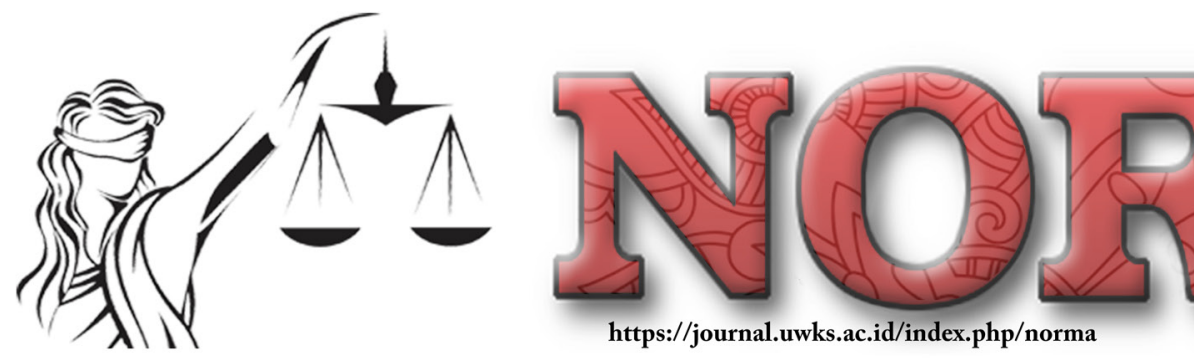

\title{
Coffee Shop Businesses (Kepengen Coffee) to Survive the Economic Effects of a Pandemic by Restructuring Royalty Agreements
}

\author{
Ervin Kusuma Winata \\ Legal Observer \\ e-Mail: ervin.kw@gmail.com
}

\begin{abstract}
:
Economic globalization in the last decade is developing very fast, the business world is always moving dynamically, business people are always looking for breakthroughs in growing their businesses one of which is a franchise system with the principles contained in the franchise agreement, but many companies are stalled due to co-19 virus pandemic so entrepreneurs must innovate and restructure to support the business. This is empirical legal research. The result of this paper is that principle of franchising is a pillar in a franchise agreement, and the parties in the franchise agreement have adhered to this agreement so that both parties need to fulfil these principles, due to the law that occurs due to a pandemic is a corporate restructuring and temporary agreement changes. The franchisor must think of regulations that benefit the franchisee with little risk. In restructuring the company and agreements, the franchisor must accurately measure the impact of the covid-19 pandemic on the franchisees' outlets.
\end{abstract}

Keywords: Franchising, Principles, Restructuring

\author{
Article's History: \\ Received: \\ 6 November, 2020; \\ Received in revised form: \\ 5 February, 2021; \\ Accepted: \\ 5 February, 2021; \\ Published: \\ 6 February, 2021.
}

DOI:

10.30742/nlj.v17i3.1074

\section{INTRODUCTION}

Economic globalization in the last decade has increased. Indonesia's presence in the economy has begun to be glimpsed by many foreign entrepreneurs, which demanded Indonesia to develop in various business sectors. Of course, rapid economic development also requires legal institutions' readiness and capability in the following economic effects due to globalization. The business world is always moving dynamically, and business actors are always looking for breakthroughs in developing their business. This is increasingly felt in the current global era where the business world's expansion has penetrated the boundaries of space, time and territory.

The current economic position has also been severely affected due to the Covid-19 virus pandemic, which has been increasing in Indonesia since February 2020. Many economic activities have stopped worldwide, which is very much felt in Indonesia, both large companies and startups. Also, with companies with a franchise model. 
The franchise as a form of business has received a lot of attention from business people because it can be a way to increase economic activity and provide opportunities for the economically weak to do business, this means that franchisees can offer employment opportunities, equity and also create community employment.

A franchise is the owner of a trademark, name, trade, trade secret, patent, or product (usually called a franchisor) that grants a license to another party (usually called a franchisee) to sell or service a derivative under the franchisor's name. Franchisees generally pay some payment-fee (royalty) to the franchisor for the activities they do. ${ }^{1}$ Franchise is a contract agreement to use the name, trademark and logo of a particular company from the franchisor, including an overview of its operating regulations by the company that uses (franchise), services provided by the franchisor, and financial requirements. ${ }^{2}$

For some entrepreneurs who wish to develop their business, this system is considered adequate and appropriate in developing a company. The emergence of a franchise business certainly brings a logical consequence to the world of law; a proper legal institution is needed to regulate the industry in a country, to create legal certainty and protection for the parties involved in this business.

In this franchise, as a license can be said, as part of the compliance of the business partner with the rules of the game given by the franchisor, the business partner is given the right to take advantage of Intellectual Property Rights and the operating system of the franchisor entrepreneur, both in the form of brand use. Trademarks, service marks, copyrights on logos, industrial designs, patents in the state of technology, or trade secrets. The franchisor will then receive a royalty reward for using their Intellectual Property Rights and operating systems by the franchisee. Brands are assets that create value for customers by increasing satisfaction and rewarding quality. ${ }^{3} \mathrm{~A}$ franchise model business's advantage is that there is no need to build a brand anymore; the franchisor will provide training, coaching, and guidance to the franchisee.

With the current proliferation of franchise businesses, the government considers it necessary to know the legality and bona fides of the franchisor's business both from abroad and within the country to create transparency of business information that national companies can optimally utilize in marketing goods and/or services with franchising. Besides, the government can monitor and compile Franchise data both the number and type of business being franchised.

The government has regulated franchise arrangements by issuing RI Government Regulation No. 16 of 1997 concerning Franchising and Decree of the Minister of Industry and Trade of the Republic of Indonesia Number: 259/MPP/Kep/7/1997, dated July 30,

${ }^{1}$ Abdul R. Saliman. (2014). Hukum Bisnis Untuk Perusahaan Teori dan Contoh Kasus. Jakarta: Kencana Prenadamedia Group, p. 58.

${ }^{2}$ Lantip Susilowati. (2013). Bisnis Kewirausahaan. Yogyakarta: Teras, p. 49.

${ }^{3}$ Hermawan Kartajaya. (2010). Brand Operation. Jakarta: Esensi Erlangga Group, p. 67. 
1997, concerning Provisions and Procedures for Implementing Franchise Business Registration, and subsequently amended by Government Regulation No. 42 of 2007, as well as Regulation of the Minister of Trade of the Republic of Indonesia Number: 53/M-DAG/PER/82012 concerning Franchising.

The explanation regarding franchising has also been regulated in the Government Regulation of the Republic of Indonesia Number 42 of 2007 concerning franchising, which has been defined in Article 1 point 1 that franchising is a special right owned by an individual or business entity against a business system with business characteristics to market goods and/or services that have proven successful and can be utilized and/ or used by other parties based on a franchise agreement."

The franchise business world will involve several parties, both from the owner or the franchisor called the franchisor, and the party gave or received a franchise called the franchisee. ${ }^{4}$ Business developments that involve more than one party, such as a franchise business, must agree on a basis for legal protection. This cooperation agreement is made in the franchise as an aspect of legal protection for the parties from causing harm to other parties.

To carry out work, the franchisor certainly needs to pay attention to the franchisee recipient's outlet and needs to evaluate its performance and make a series of improvements, so that it continues to grow and be competitive. These improvements will be carried out continuously so that the company's performance will get better and continue to excel in the competition or remain sustainable. One of the strategies to improve and maximize company performance is by restructuring. ${ }^{5}$

Many companies restructure to keep up with the times and consider several parties concerned with the company. Organizational restructuring or organizational design is defined as formal mechanisms by which the organization is managed. The corporate structure shows the framework and arrangement of a fixed pattern of relationships between functions, parts or positions, and people who lead, different duties and responsibilities within an organization.

The existence of restructuring will be expected to produce a lean, flexible, efficient, responsive structure and respond to problems that previously existed in the company. One example of the restructuring process is the impact of the Covid-19 virus pandemic. Several regions in Indonesia have implemented the PSBB (Large-Scale Social Restrictions), aiming to reduce the level of the Covid-19 virus in Indonesia. This PSBB regulation by the government is a harmful impact for entrepreneurs because of the community's reduced activity, which decreases their income.

${ }^{4}$ Cita Yustisia Serfiyani. (2015). Franchise Top Secret (Ramuan Sukses Bisnis Waralaba Sepanjang Masa). Yogyakarta: Andi, p. 15.

${ }^{5}$ Griswanti Lena. (2005). "Perlindungan Hukum Terhadap Penerima Lisensi Dalam Perjanjian". Tesis. Universitas Gadjah Mada, p. 87. 
The number of businesses affected by the Covid-19 virus pandemic makes entrepreneurs innovate and restructure to support the company's running. Of course, the franchise system also experiences it, so Kepengen coffee also carried out many innovations and restructuring during this pandemic. One of the creations carried out by Kepengen coffee is the Franchise arrangement associated with the payment model, raw materials for the food and beverage menu, the form of outlet working hours, customer service and so on.

This pandemic condition itself cannot be described as a force majeure, which is a condition that occurs after an agreement is made that prevents the debtor from fulfilling his performance, in which the debtor cannot be blamed and does not have to take risks and cannot predict when the agreement is made. Because all of that before the debtor was negligent in fulfilling his performance when the situation arose, the franchisor used another method: company restructuring. ${ }^{6}$

Franchise innovation will also involve the right to use and intellectual property rights or inventions or business characteristics, which is meant by intellectual property rights including, among others, brands, trade names, logos, designs, copyrights, trade secrets and patents, and what is meant by business inventions or characteristics, namely the management system, sales or arrangement or distribution methods which are the unique characteristics of the owner.

Franchise business the use of intellectual property rights by franchise recipients will be subject to royalty fee payments, royalty itself is defined as compensation for granting permission to use economic fairness, so the creator or right holder will receive a royalty fee. This royalty is a means of obtaining financial benefits for creators or rights holders. So, if other parties use economic rights without permission, the creator does not get royalties, which means losing their economic rights. These other parties are not entitled to get financial benefits by illegally commercializing the creator's work. So, it needs protection to creators or rights holders, especially for violations of economic rights.

Kepengen coffee management practice that this royalty is a fee to lend a license to maintain and improve the brand. As Kepengen coffee owner, the franchisor uses Royalty fee as one of the agreement's terms to increase his business. The Royalty fee payment system agreement model is carried out every month on the 15th; the franchisor has calculated the royalty fee not to burden the franchisee.

\section{PROBLEM FORMULATION}

Royalty Restructuring of Kepengen Coffee Through an Agreement in The Pandemic Time.

\footnotetext{
${ }^{6}$ P.N. H. Simanjuntak. (2017). Hukum Perdata Indonesia Cetakan ke-3. Jakarta: Kencana, p. 295.
} 


\section{RESEARCH METHOD}

This research is empirical legal research. This research was conducted by direct study at one of the coffee shops, mainly studying the Franchise Agreement.

\section{DISCUSSION}

The franchise agreement that the researchers will use in this study is the Kepengen Coffee franchise agreement for the Purwokerto branch, in this Kepengen Coffee franchise agreement several aspects already exist in this franchise agreement, including:

a) Date, day and place agreement agreed upon;

b) Name, address, and some data from each party;

c) Intellectual property rights and form of the business entity;

d) Characteristics of business and business activities.

Some of the above aspects are in the Kepengen coffee franchise agreement because it is a minimal aspect in a franchise agreement, and the writing standard has followed PP. 42 of 2007 concerning franchise agreements in Article 3 and Article 5.

Kepengen Coffee is in the form of a Commanditaire Vennootschap (CV) business entity. With business activities selling beverage products, data in the form of names and KTP numbers have also been written, legally for IPR; especially trademark registration has also been registered.

Then the obligations and rights that each party will receive are written in the franchise agreement article 2 to article 5. Article 2 explains that this agreement guarantees licenses and exclusive rights to the coffee maker in Purwokerto.

In the franchise agreement for kepengen coffee, you can find several principles in Kepengen coffee, including:

a) Properly train and set up new franchises.

1) This principle can be seen in article 10 of the franchise agreement entitled "Recruitment and Training", the franchisor will schedule direct training at the outlet to be opened, but all costs incurred during training will be borne by the franchisee;

2) Not only at the opening of outlets but this training is also allowed if there are old employees who leave and require training for new employees, but when there is product standardization to the making of new recipes, the franchisor will bear the costs incurred;

3) The purpose of this training itself is to maintain operational standards and quality control for each new Kepengen coffee shop that has just opened; this training is also given every time a recipe is added;

4) If seen in PP. 42 of 2007 regarding franchising, we can see in article 8 it reads "Franchisors are required to provide coaching in the form of training, 
operational management guidance, marketing, research, and development to the Franchisee on an ongoing basis.";

5) In-person training is carried out for four days at the Kepengen Coffee shop which is ready to operate, the training conducted by the franchisor to the franchisee includes:

i. Train to make beverage product recipes;

ii. Train the use of cashier and accounting systems;

iii. Train standard operating procedures from Kepengen coffee;

iv. Train and help on the first opening day;

v. Train standard operating procedures for hygiene at Kepengen coffee;

vi. Train product ordering ingredients standard.

6) This training is provided so that franchise recipients can run the system correctly from ordering raw materials, manufacturing products, recording sales, to applicable operational standards such as cleanliness to greeting methods;

7) Coaching is carried out in 2 forms, namely offline and online if it is not possible to do it offline.

b) Measuring franchise performance and evaluation of franchise financial performance on a scheduled basis.

1) In addition to preparation and training, the franchisor also routinely conducts unannounced inspections of its outlets. The goal is that the franchisee can continue to follow the franchisor's standard operating procedures.

2) In addition to training from the franchisor's management, it will also carry out routine checks on each kepengen coffee outlet; the government will recap the sales data of each outlet every month. It will hold a meeting if there is an outlet that is having trouble in any way. The objectives of the performance evaluation consist of:

i. Increase mutual understanding between employees about performance requirements;

ii. Recording and acknowledging the work results of an employee, so that they are motivated to do better, or at least have the same achievement as previous achievements;

iii. Provide opportunities for employees to discuss their wants and aspirations and raise awareness of their current career or job;

iv. They are defining or redefining future goals so that employees are motivated to achieve according to their potential.

v. Examine the implementation and development plan according to the training needs, precisely the training plan, and then approve the project if there are no things that need to be changed. 
vi. The purpose of measuring franchise performance and evaluating the financial performance of the franchise itself is a form of supervision from the franchisor to see whether the Kepengen coffee shop is running well, if it does not work well then the franchisor will hold meetings and provide guidance to franchise recipients such as product marketing, product training, to standard operating procedures that need to be carried out.

In Government Regulation No. 42 of 2007 concerning franchising, it is also explained in CHAPTER IV Article 14 with the title Development and Supervision with the following criteria:

a. The Government and Regional Governments conduct Franchise development. The guidance as referred to in paragraph (1) includes, among other things, the provision of:

1) Franchise education and training;

2) Recommendations for utilizing marketing facilities;

3) Recommendations for participating in Franchise exhibitions both domestically and abroad;

4) Consulting assistance through business clinics;

5) Award to the best local franchisor; and

6) Capital strengthening assistance.

Measuring the performance of the franchisee can help the franchisor to see which outlets are operating well and which outlets are experiencing difficulties, by looking at the number of sales and performance of outlets that are experiencing difficulties, the franchisor can provide consultation with these outlets, what problems they are dealing with in an effective way of marketing.

Franchisors can achieve a profitable ROI without having to deliver outstanding performance. ROI stands for Return On Investment, meaning ROI or Return on Total Assets is a measurement of the overall company's ability to generate profits with all the assets contained in the company. ${ }^{7}$

Return On Investment (ROI) is the company's ability to generate profits from investment". The greater the ROI shows, the better its performance, so it is natural that shareholders expect the distribution of cash dividends if the ROI increases. ${ }^{8}$ The franchisor's management's ROI calculation is given since the proposal stage, with the hope that the franchisee can calculate the ROI required from the state of their outlets.

The franchisor will assist the ROI calculation itself before the contract signing agreement to help calculate the ROI of Kepengen coffee shops with conditions that

\footnotetext{
${ }^{7}$ Agus Sartono. (2010). Manajemen Keuangan Teori dan Aplikasi. Edisi 4. Yogyakarta: BPFE, p. 73.

${ }^{8}$ Edi Sutrisno. (2009). Manajemen Sumber Daya Manusia. Edisi Pertama. Jakarta: Kencana Prenada Media Group, p. 10.
} 
adjust the prospective franchisee's wishes. The ROI calculation table itself will be attached on the attachment page.

The Kepengen coffee franchise agreement has also been written in full, the prohibitions on the franchisee's veto, and what rights are received by the franchisee. When one of the parties violates the applicable provisions, it will refer to the franchise agreement article 23 concerning dispute resolution.

The settlement of this dispute is carried out in deliberation before using legal channels to the public court. In the kepengen coffee franchise agreement, it is also written that the parties agree that all businesses have risks.

Principles of Marketing Area and business location. The guide is carried out so that franchisees have their respective locations to make sales and avoid unfair competition against other franchise recipients who hold the same brand. Before being opened by the franchisor's outlet, the area of the business must pass checking and approval by the franchisor to avoid the location of the outlets that are too close together. If the franchisee forces to open an area adjacent to another franchisee, it must be approved by the franchisee who opened earlier.

The franchisor's regulations regarding the marketing area and business location are that each city has a maximum limit for opening outlets. The location of each outlet must be at least $4 \mathrm{~km}$ in radius. Changes in the business location are allowed but must report back to the franchisor first, for double-checking. With the principle of regulating the marketing area and business location, the franchisor aims to compete fairly and have their respective marketing areas.

Principle of Franchise Fee and Royalty Fee Payment. Royalty is often called continuous franchise money. The money is a payment for ongoing services provided by the franchisee. ${ }^{9}$ The amount of royalty fee payments is linked to a certain percentage calculated from the production and sale of goods or services that contain franchised Intellectual Property Rights. ${ }^{10}$

The principle of paying franchise fees and royalty fees has also been regulated in article 8 and article 9 of the kepengen coffee franchise agreement, for the franchise fee payment itself will be paid when the franchise agreement is signed, and a royalty fee will be paid every month after the outlet opens.

The franchisor's system for royalty fees has also been calculated so that it does not burden the franchisees, and this royalty system is used because the franchisees use intellectual property rights.

In addition to the use of intellectual property rights, the franchisor also uses these funds to continue to innovate needed, so that the brand image and business development of Kepengen coffee do not stop at one point but can continue to grow so

\footnotetext{
${ }^{9}$ Darmawan Budi Suseno. (2007). Sukses Usaha Waralaba. Yogyakarta: Cakrawala, p. 19.

${ }^{10}$ Widjaja Gunawan. (2004). Lisensi atau Waralaba. Jakarta: Rajawali Pers, p. 177.
} 
that franchise recipients can more easily make sales, in addition to development. Brand image, funds from royalty fee are also used for development through marketing; the franchisor uses royalties as a way for Kepengen coffee to continue to grow.

Looking at the above principles, we can see that the Kepengen Coffee franchisor has considered many things and has a goal so that the Kepengen coffee shops opened by franchise recipients can run well and smoothly.

These principles are also a guide between the franchisor and the franchisee. These principles are also the SOP (Standard Operational Procedure) of Kepengen Coffee so that each Kepengen Coffee outlet can maintain the brand image of the Kepengen Coffee business, which of course is not detrimental. The Kepengen coffee franchise recipient at other outlets or branches, by keeping the brand image, hoped that Kepengen Coffee parties could continue to compete healthily and achieve ROI sooner or later.

\section{Legal Repercussions and on Franchise Agreements in Pandemic Conditions}

This virus pandemic has had a significant impact on business people with several areas that have implemented the PSBB (Large-Scale Social Restrictions), which has reduced many community activities.

This study's results are that the franchisor has seen and anticipated what will happen with the implementation of the PSBB and the increasing number of Covid-19 patients. The franchisor has distributed the latest circular to franchisees in early April because he saw the growing spread of the Covid-19 virus. 19 in Indonesia.

Some of the points conveyed in the circular letter were a reduction in Royalty fee of 500,000 rupiahs from the original 1,000,000 rupiahs. The purpose of this cut was to reduce the burden on franchisees during this pandemic.

Besides, there is also a policy for purchasing raw materials at a discount of $10 \%$ during the pandemic, which is where this regulation takes effect from April 1 - July 1 2020. Several points conveyed that franchise recipients are required to follow each applicable region's protocol regulations, such as the use of masks, up to the applicable operational hour deadline.

Researchers also asked whether any outlets were closed during this pandemic and whether the outlets' closure was a force majeure. In this case, the franchisor explained that the current position was not said to be a force majeure because this virus pandemic actually did not come suddenly and its movement gradually.

So in the agreement, the parties can anticipate first. In addition to a few points from the circular letter to cut the franchisor's operating expenses as management, it can start existing efforts to sell each outlet so that it does not decline.

These efforts include issuing new innovative products such as drinks made from ginger, which are spices that can strengthen the immune system and see the convenience of customers such as online payment methods that have been provided 
and online ordering methods have also been prepared. This effort was carried out so that the closure of outlets during this pandemic could not be mentioned as one reason for force majeure by the franchisee.

From this research, it is hoped that we can gain knowledge that several legal consequences have changed from the agreement that was agreed upon from the start. Some of the changing legal matters are seen in Article 9 regarding Royalty Fee in the Kepengen coffee franchise agreement which states, "For granting the right to run a Kepengen business as referred to in Article 2 at a Business Location, FRANCHISOR is charged to pay a royalty fee of Rp. 1,000,000 (one million rupiahs) per month."

The consequence of the agreement, which has initially been every month, the franchisee was required to pay a royalty fee of 1,000,000 rupiahs, but during this pandemic, it was only 500,000 rupiah. By seeing the Royalty fee change, we can see that the franchisor is restructuring the agreement even though it is temporary. The royalty fee does not burden the franchisees during the pandemic.

Article 22 of the agreement define regarding Force Majeure in the Kepengen Coffee franchise. This article explained that the force majeure in the form of natural disasters, wars, blockades, and rebellions sabotage, civil unrest. So there is no pandemic condition this virus cannot be used as a force majeure reasons. ${ }^{11}$

In making amendments or restructuring this agreement, the franchisor has provided information via a circular to all franchisee; this circular will be attached on the attachment page. Franchisors have restructured the system by preparing and making innovations to ensure franchise recipients can survive during the Covid-19 pandemic.

\section{CLOSING}

\section{Conclusion}

The franchise agreement from Kepengen coffee includes the terms and conditions in a contract. From the Kepengen coffee agreement, we can take several applied principles, among others train and prepare franchise new correctly, measure franchise performance evaluation of franchise financial performance on a scheduled basis. Equality before the law Marketing area and business location franchisors can achieve a profitable ROI without delivering outstanding performance: franchise Fee Payment and Royalty fee. These principles will be the pillars in a franchise agreement, and the parties to the franchise agreement have already adhered to this agreement so that both parties need to fulfil these principles. The legal consequences of the accords agreed during this virus pandemic. Several changes are temporary, intending to reduce the cost burden of each kepengen coffee shop. Forms of renewal of this franchise agreement, including payment of a royalty fee of 500,000 rupiahs from the last 1,000,000 rupiahs per month. The arrangement of franchise outlets follows all the requirements set by

\footnotetext{
${ }^{11}$ P.N. H. Simanjuntak. (2017). Hukum Perdata Indonesia Cetakan ke-3. Jakarta: Kencana, p. 295.
} 
the government regarding the Covid-19 pandemic, for example Working hours from 12:00 to 20:30 (one shift is made) Payment model with the online payment system Ovo, Gopay) Social Distancing (minimum distance setting 1 meter) Ordering system (online ordering system and take away only)

\section{Recommendation}

The franchisor should consider the long-term benefits principle so that franchisees can also benefit more and have less risk. The agreement between the parties needs to be made. A decision that contains the franchisor must measure accurately following the impact of the Covid-19 pandemic, such as government regulations in the Minister of Health Regulation No. 9 of 2020 and the respective regional heads' regulations. Following what happened at each franchise outlet. The franchisor then manifests this to the franchisee in the form of a circular distribution regarding information about force majeure during this pandemic.

\section{REFERENCES}

Peraturan Pemerintah Republik Indonesia Nomor 42 Tahun 2007 tentang Waralaba Peraturan Menteri Kesehatan Nomor 9 Tahun 2020 tentang PSBB

Abdul R. Saliman. (2014). Hukum Bisnis Untuk Perusahaan Teori dan Contoh Kasus. Jakarta: Kencana Prenadamedia Group.

Agus Sartono. (2010). Manajemen Keuangan Teori dan Aplikasi. Edisi 4. Yogyakarta: BPFE. Cita Yustisia Serfiyani. (2015). Franchise Top Secret (Ramuan Sukses Bisnis Waralaba Sepanjang Masa). Yogyakarta: Andi.

Darmawan Budi Suseno. (2007). Sukses Usaha Waralaba. Yogyakarta: Cakrawala.

Edi Sutrisno. (2009). Manajemen Sumber Daya Manusia. Edisi Pertama. Jakarta: Kencana Prenada Media Group.

Griswanti Lena. (2005). "Perlindungan Hukum Terhadap Penerima Lisensi Dalam Perjanjian". Tesis. Universitas Gadjah Mada.

Hermawan Kartajaya. (2010). Brand Operation. Jakarta: Esensi Erlangga Group.

Lantip Susilowati. (2013). Bisnis Kewirausahaan. Yogyakarta: Teras.

P.N. H. Simanjuntak. (2017). Hukum Perdata Indonesia Cetakan ke-3. Jakarta: Kencana. Widjaja Gunawan. (2004). Lisensi atau Waralaba. Jakarta: Rajawali Pers. 